\title{
4 Culture as Cause
}

Wisdom has it that individuals amount to the sum of their general tendencies, which in the long run must shape their life's course. An entire people, too, may be characterized in this same way. It is a common belief, witness a recent piece in the Times finding a half dozen European nations and Americans, too, from the sixteenth century to the 1980s, defined and defining each other, mostly in unflattering terms.

Those stereotypes to which the man in the street reduced his neighbor states found no support in social science research, so it seems; and intellectuals didn't do much better. They spoke of national character in dreamy terms like Geist, génie, "essence”, or "soul". Or worse: they might ask their readers to accept collective "genius" as a matter of "inherent hereditary traits of a biological and psychological nature", or similarly, "innate racial characteristic", according "to current assumptions" - this said in $1924 .{ }^{1}$ Such ideas were a problem in the inter-war period, notoriously.

Thereafter, though stereotyping of nations continued unabated in the public media and popular discourse, there has been little serious history written in such terms. It could only be agreed that, at a more sophisticated level, differences among nations did and do exist, if perhaps exaggerated or misunderstood or "inaccurate" by some metric; and such differences are "cultural"; ${ }^{2}$ but beyond that, national character as a tool of historical study, at least in the usual terms, has enjoyed little favor. ${ }^{3}$

Instead, explanation for historical events and developments should be sought, not in an entire people's settled tendencies but rather in the operation of the external stimuli of the moment, in surrounding circumstances - "situationally" as psychologists would say. Circumstances and stimuli should be assessed calculatingly, cognitively, in defined settings. The process had a reassuring rigor about it. A passage drawn more or less at random from the hugely admired Fernand Braudel may serve in illustration:

The fundamental characteristic of Philip II's empire was its Spanishness - or rather Castillianism - a fact which did not escape the contemporaries of the Prudent King, whether friend or foe: they saw him as a spider sitting motionless at the center of his web. But if Philip, after returning from Flanders in September, 1559, never again left the Peninsula, was it simply from

1 Ben Schott, "Vive la différence," New York Times 19 January 2011, A23, over fifty of such pithy characterizations in Robert Burton, Mark Twain, proverbs, and so on; but such stereotyping is most often mistaken, cf. the fullest study by questionnaire across dozens of countries, Terraciano et al. (2005), though with criticism of this study, above, chap. $1 \mathrm{nn}$. 34f. Hume's essay "On national characters" (1987) 197-213 is predictably full of sense; and on innate "national genius" and the like concepts, see Sapir (1924) 405f., quoted.

2 Laitin and Gordon (1998) 429, Robins (2005) 62, Smith et al. (2006) 56f. and 77, or Mesquita and Leu (2007) 738.

3 See, e.g., Wilterdink (1994) 43, Benthall (1997) 612, or Higgins et al. (2008) 162. Undeterred, I used national character as key to my understanding of ancient Rome, in MacMullen (2011). 
inclination, from a pronounced personal preference for things Spanish? Or might it not also have been largely dictated by necessity? We have seen how the states of Charles V, one after another, refused to support the expense of his campaigns. Their deficits... [and so forth]. ${ }^{4}$

Braudel deliberates. Did the king and his subjects have a love or liking for one style of life over another, perhaps unreasonably? Philip was human, after all. We can try to read his face in his portrait in London or Madrid. But on reflection, it would be best for us to assume he was rather rational in his behavior, and in that assumption we should try to read his mind through the available statistics of international commerce, banking, population, and so forth.

Or here, a second example of method in another style but of the same generation. At school, my own introduction to history was a two-volume textbook approved in one edition after another for over half a century. On a quite typical page is an account of the U.S. reaction to waves of revolt among Spain's colonial possessions in the earlier 1800s. The Secretary of State under President Monroe, John Quincy Adams, informs a leader in Congress that, while he had wished the revolutionaries well, he saw no chance that U.S. support could work out for the nation. He contrasts what the revolutionaries have always had to submit to, with what they longed for: "Arbitrary power, military and ecclesiastical, was stamped upon their habits, and upon all their institutions. Civil dissension was infused into all their seminal principles... I had little expectation of any beneficial result to this country from any future connection with them, political or commercial." And "this passage," my textbook continues, "reveals the policy of Monroe's administration toward the Latin Americans. Their independence was desired as an additional bulwark for American isolation; but not with sufficient ardor to risk a European war." ${ }^{5}$ The Secretary's words and train of thought are noted and his weighing of the most likely results of one policy over another: a "beneficial result" and consideration of factors "political" and "commercial". Here are calculation and cognition. The substance that the Secretary considered could at the time be observed and quantified: so many tons of imports, so many votes, and so forth. He was a calculating man, as was his President likewise.

What interests me is the preference demonstrated by the French historian and the two Americans for explanation in rational and situational terms. This they chose over attachments and passions, traditional values, attitudes, or collective self-image which they nevertheless acknowledge before turning away. Our natural human, more or less innocent post-facto rationalizing of our actions was noted in earlier chapters. ${ }^{6}$ It infects historiography as well. And why not? About irrational factors, conclusions must remain uncertain, sometimes unreasonable because they can amount

4 Braudel (1972-73) 2.676, continuing (678) with a general recommendation to historians that they interpret political history by demography, ups and downs of commerce, and the like factors.

5 Morison and Commager (1942) 1.453f.; the book had its final edition in 1980.

6 See especially chap. 3 at n. 51 . 
to no more than guesswork about intangibles lying half-hidden behind what is observed and open to our five senses.

But the idea discarded by the historians - that collectivities are like individuals and have personalities, and it is traits that constitute both personality in individuals and culture in whole societies, shaping response in the decisions of the moment - this idea perhaps deserves a second hearing. In support I would cite the EVS (European Value Studies)/WVS (World Values Surveys), by now well known. They are the work of social scientists and theology scholars jointly at a Dutch and a Belgian university in 1981, growing out of some years of prior research and resulting in a questionnaire. It asks of each respondent how important family is, or religion, or leisure; which women's groups or sports associations they belong to; why one might or should do voluntary work; the significance of risk-taking in success; whether cheating on taxes is ever justified; how interested one is or should be in politics; and so on, in depth after depth. For its operations, large, randomly selected samples of respondents from among the fifteen countries of the European Union were polled face-to-face, and with minor improvements the process was subsequently repeated at several intervals to extend its reach almost everywhere around the globe. ${ }^{7}$ The sixth repetition reached into 2012. For my purposes, what counts in this thirty-year effort is, first, the underlying belief in the distinct character of the Latvians, the French, and so forth, discernible in their commonly held beliefs, norms, and ethical standards, amounting to the validation of national character as a concept; and further, an underlying belief in the effect of all these many aspects of culture on collective institutions, including the economy. ${ }^{8}$ The importance of economic behavior in my earlier chapters makes this aspect especially useful for my purposes; and both the EVS and WVS have from the start shown much interest in the norms and beliefs underlying prosperity.

"The idea that economic growth is partly shaped by cultural factors has encountered considerable resistance"; ${ }^{9}$ but in answer it could be pointed out that the problem lay in the false perception of all Germans as forever militaristic, Hispanic culture forever unfavorable to development, and similar stereotypes. They were wrong because (whether or not they had ever been justified) it could be shown by statistical evidence from the EVS/WVS, that cultures in recent decades in fact show change. Cultural history is dynamic, not static. There need be no claim that norms and beliefs entirely determined the course of economic development - only that these factors have a causal role along with the more familiar direct influence of raw mate-

7 On sampling technique, see Inglehart et al. (1998) 15, 467, 470ff., with hundreds of pages of the results of the 1990 WVS, showing the variety of the questions, while Halman et al. (2005) use over sixty maps to show national differences under some dozens of rubrics ("work ethos", "importance of God", etc.) across all of Europe.

8 Arts et al. (2003) 4 and, on economic values shaped by non-pecuniary preferences, 408 and Muffels (2003) 437.

9 Quoted, Granato et al. (1996) 624. 
rials, political stability, technology, command of capital, and so forth. Here, value surveys permit multivariate analysis, if not demonstration: for example, through the measurement of the common emphasis on thrift and determination in children's upbringing, as against obedience and religious faith, in Korea as against Nigeria, and measurement of the value generally set on achievement in those two and many other societies, graphically represented. ${ }^{10}$

The analytical model of course brings to mind Max Weber, who is seen as a respected presence, indeed "a founding father of sociology", in the community that has supported the EVS/WVS; and Charles Tilly recently reminded his colleagues in that discipline that any general discussion taking off from a classical authority like Weber cannot go wrong. ${ }^{11}$ It was in 1904/5 that Weber addressed national character, "Volkscharakter", in a work appearing as two halves in successive issues of a scholarly journal. ${ }^{12}$ The Protestant Ethic and the Spirit of Capitalism was greeted with the greatest interest, and keen criticism, too, to which he responded when, fifteen years later, the two halves appeared in normal fashion as a book (1920). It may be called the first serious application of social science to the past, by a figure much in the public eye at the time as both an academic who straddled several fields and as a commentator on large questions of the day. He combined immense intellectual energy with an immensely wide embrace of facts and ideas, warranting the reception his book received and insuring for it a place in subsequent sociology and historiography to the present day.

He chose a straightforward title, indicating pretty well what he was about: an analysis of the theology of Lutheranism so far as it bore on salvation, and in turn, how such beliefs influenced or even dictated a certain course of life. He called them "culture", or sometimes "life-style" or "attitude", most often "spirit”. Shortly after the book was published, when Weber was involved in replying to a critic, he also used the term "habitus". ${ }^{13}$ Luther's reforms, as Weber argued, had been soon taken up by independent-minded followers, giving rise to Calvinism and derived sects like Mennonism. In these Weber discovered an explanation for important changes in economic behavior. As he saw it, these changes constituted the very building materials of

10 Granato (1996) 607, 613 (complementary causal roles); 624, European national character is dynamic in recent decades; 621 Fig. 2, showing the relation of achievement motivation to economic growth; and 611 and Inglehart et al. (2000) 24, inculcation of economically relevant values in childhood.

11 See, e.g.. Granato et al. (1996) 608-11 or Arts et al. (2003) 4; also Tilly (2003) 2f.

12 Weber (1920) 1.164, 194; (2008) 155, speaking loosely of any nation; 173, speaking of Britain. He puts the word "Volkscharakter" in quotation marks not to disavow it but to show its particular place in his argument, as he does with many other terms, e.g., (1920) 61, “Geist”. Werner Sombart as Weber’s contemporary was active in closely related questions but was never a match for Weber.

13 Weber (1920) 100, “Kultur”; 183, 191; or 203, “Lebensstil”; 202, “Gesinnung”; 12, similarly and close to traits, "Disposition der Menschen”; and habitus in 1922 used to explain Lebensstil, cf. Lehmann (2005) $14 \mathrm{f}$. 
modern capitalism, of which the seventeenth century was "the heroic age". ${ }^{14}$ By the eighteenth, the patterns of behavior necessary for the spread and success of capitalism had been established even though religious inspiration had faded out of it. Such in brief is "the Weber thesis" - omitting, however, its genesis.

The attention of Weber himself and of others in the decades before he wrote had been attracted to a curious fact: that German Catholics quite noticeably preferred to send their sons to study the classics and humanistic subjects whereas Protestants sought to acquire science, mathematics, and skills useful in the real world. ${ }^{15}$ Further, it was noticed that the Catholic population settled into traditional ways of earning a livelihood at a traditional pace and with traditional expectations, whereas Protestants more commonly occupied mid-level or high administrative positions in commerce or manufacture, giving themselves with tireless devotion and planning to their business so as to make it ever larger and better regulated. Their business was their calling, as God determined it, whether the most humble or the most rewarded; as God required, so his people must live out their sense of obligation. This was "absolutely central" to the making of capitalist man. ${ }^{16}$

In describing their common traits and goals Weber constantly uses the terms "rational" and "rationalization" or rough equivalents. Typically, a Protestant day like Protestant dress and Protestant furnishings at home must be thought-out, orderly, and controlled, where controlled meant also spare and self-denying, all directed "to the greater glory of God". Every moment's choice of conduct must reveal whether divine grace was at work and so whether one was among the Elect to be saved. To the observer, the life lived in this way could only seem strangely monastic, indeed "irrational". It is a "secular asceticism" in Weber's phrase, "which tried to enable a man to maintain and act upon his constant motives, especially those which it taught him itself, against the emotions. In this formal psychological sense of the term it tried to make him into a personality". ${ }^{17}$

Once established in various forms and sects in western Europe and, by emigration, in America, the personality-type proved itself in economic success even after its theological basis had faded. The habit or habitus to be seen in the rational inventory both of one's self, sometimes by a diary, and of one's business, served Protestants

\footnotetext{
14 Weber (2008) 166.

15 McClelland (1961) 320ff., confirming Weber with better statistics.

16 "The God of Calvinism demanded not single good works... but a life of good works combined into a unified system", and "it is an obligation which the individual is supposed to feel and does feel towards the content of his professional activity", Weber (2008) 117, "eine zum System gesteigerte Werkheilgkeit" ("a piety in work that rose to the level of a system") and 54, "der beruflichen Tätigket"; and "the sense of obligation was absolutely central", Weber (1920) 47.

17 "The ideal type" of capitalist "gets nothing out of his wealth for himself, except the irrational sense of having done his job well," in the words of Weber (2008) 71, (1920) 55. On "secular asceticism”, “innerweltlich Askese”, see Weber (1920) 84-163; quoted, Weber (2008) 119, (1920) 117.
} 
well. It "is mentioned by all the moralists and theologians, while Benjamin Franklin's tabulated statistical book-keeping on his progress in the different virtues is a classic example."18

In the months in which Weber was composing the earlier half of his work America was much on his mind, and immediately after he finished correcting the proofs of his text he made a visit there to learn more of its ways. He had earlier read and in his book often cites Franklin's autobiography and provides extensive quotations also from Franklin as a "preacher" in his "sermons" - referring to two little booklets of advice for young men published in 1736 and 1748. Passages from them Weber had spotted in a German translation of 1855 , and he used them to lead off his chapter on "the Spirit of Capitalism". In a brief, easily understandable form they illustrated what he calls "Americanism"; they revealed exactly that spirit which he proposed to set at the heart of the developed economy of the West. ${ }^{19}$ Franklin thus was particularly well suited to Weber's argument - as to my own also.

In a characteristic page Franklin warns,

Beware of thinking all your own that you possess, and of living accordingly. It is a mistake that many people who have credit fall into. To prevent this, keep an exact account for some time both of your expenses and your income. If you take the pains at first to mention particulars, it will have this good effect: you will discover how wonderfully small, trifling expenses mount up to large sums, and will discern what might have been, and may for the future, be saved, without occasioning any great inconvenience. ${ }^{20}$

The German historian of ideas, Richard van Dülmen, sums up: "As the analysis of Franklin's habitus makes clear, instanced by Weber as paradigmatic, the new spirit of capitalism could develop not out of a materialistic striving for gain that can be seen at all times and in all places, but rather from 'ethically colored maxims for conduct in life', as Weber wrote."21

The understanding of changes on an historical scale was certainly Weber's aim, but his handling of the historical discipline as it was understood more than a century

18 Weber (2008) 124.

19 The American trip, in Dülmen (1988) 90, Lehmann (2008) 6, or Barbalet (2008) 3; anecdotes and lessons from it, Weber (1991) 302-15; Swatos and Kivisto (2005) 128, quoting Sidney Hook, "An ideal illustration of the spirit of capitalism is furnished by the writings [n. b., not the person] of Franklin. Here we have a social morality which centers exclusively around the business of getting ahead in the world”. On Franklin “preaching”, cf. Weber (2008) 50f., (1920) 33; "sermon”, (2008) 71, (1920) 55. Weber first met and then better translated the passages from Kürnberger (1890) 30ff. On “Americanism”/"Amerikanismus”, see Weber (2005) 52; (1920) 35.

20 Weber (2008) 50.

21 Dülmen (1988) 91; Sidney Hook in exactly similar terms quoted in Swatos and Kivisto (2005) 1281; and Norris and Inglehart (2011) 160f.; the ethic, 162, “a materialistic value system” (!); and 317 for bibliography on the reception of the thesis. 
ago doesn't show him at his best. ${ }^{22}$ He was better at the "ethically colored" elements, for which read, "wrapped in affect". Such were the feelings of obligation and anxiety that possessed the Protestant. Though they constituted the motivational force behind the development of the capitalist personality, he has little to say about them in themselves, calling them correctly but clinically "the psychological motives that gave direction to one's conduct of life". ${ }^{23}$ Living as he did in the midst of a capitalist society, he had no trouble with them; in his day empathic understanding reached its limit only when it encountered fanaticism, mysticism, or the like. ${ }^{24}$ Protestant zeal and suppression of the natural man was indeed, in an instrumental sense, fully rational even when the vocation for its own sake governed decisions and lifelong efforts were continued beyond the point of attaining wealth. If instead the natural man was governed by passions, then suppression of them as the source of error made perfect sense. "Rationalism is an historical concept which covers a whole world of different things". ${ }^{25}$ For "historical” we may read "cultural".

The personality-type mentioned above, or in Weber's term the "ideal-type", does suggest itself on many a page of The Protestant Ethic, changing somewhat over time, a figment useful in explaining complicated historical processes. Weber brought out the possibilities of such and similar concepts in other writings, too. They were not offered as objective science. He did not expect the individual driven by the Protestant ethic, in his own day or Franklin's or in earlier centuries still, to answer precisely to any real actor in history; nor did he think it necessary fully to understand such a person, intellectually, where empathy could be invoked to better effect. ${ }^{26}$ Subjectivity was in fact inevitable. For his argument it was sufficient to sense a style of life in accordance with certain values as he had seen it in America or in his own

22 It would be easy to instance scholarly criticisms of Weber as a historian, as, e.g., in Furnham (1990) 2-7, Landes (1998) 176f. citing critics (but Landes himself, 177-81, is a defender of Weber) or Barbalet (2008) 7, 21, 24, etc.; but my own criticism might begin with his hopping in a few lines from the third century Roman empire to 19th century Prussia, to explain a certain phenomenon, as if the settings were comparable, or again from the first century Roman empire to 19th century Russia, to explain another, in the same fashion, Weber (1978) 476, 484f.; or again, with an absurd generalization about Christian marriage and barbarism, Weber (2008a) 117 (top).

23 Quoted, Weber (1920) 86 on "Antriebe”, with a poor translation in Weber (2008) 97, "sanctions"; and emotions never given more than mere mention, e.g., Weber (2008) 112; (1920) 106, "Angstaffekte”, though they are a continuous subtext.

24 Weber did not offer his readers insights which he would have said made no sense; he abjured intuition of that sort; but he did acknowledge a role for empathic understanding, cf. Weber (1978) $5 f$. Eliaeson (2000) 249 slightly misunderstands the question.

25 Emotions are to be suppressed, Barbalet (2008) 56, 76; quoted, Weber (2008) 78; (1920) 62; and cf. above, n. 17.

26 On ideal types, see Mommsen (1989) 127 and his chapter 8, passim; Tribe (1988) 7f.; further, Weber (1978) 5, ending in the statement, that "a lower degree of certainty" than when evaluating instrumental calculations and behavior "is, however, adequate for most purposes of explanation". 
Germany, and as he had reported on it, emphasizing values as the driving force. ${ }^{27}$ It was enough, too, if report could present a good approximation. Weber's interpretive model recalls Seymour Epstein's tolerance for "predicting most of the people much of the time". ${ }^{28}$

Much in the Weberian analysis has stood up pretty well. The consensus emerging in behavioral economics over the past generation supports, if quite timidly, the recognition of affect in decision-making; the proposal that rationality is relative to a given collectivity and with it, its value system - this notion no longer seems so alarming as it once did. That values or traits like conscientiousness may have cumulative long-term effects is a common view, too, and supporters (though also critics) of the idea of a modal personality characterizing each society are easily found, for example, in anthropology. The modal personality is not much different from Weber's "ideal type". ${ }^{29}$ And of course the assumptions in the EVS/WVS underpin his thesis.

It is, however, in fitting his views into history that Weber showed the greatest ambition. Here some uncertainty appears. He speaks of "national character" in the West and specifically "Americanism" using comprehensive terms as if there were nothing to be seen or considered in these populations beyond capitalism and its ethic or values. In fact, however, the ethic he writes about nowhere governs more than a portion of society in a portion of life's values and pursuits. The vision may be too narrow for historians. If they wanted to explain the past through figments in Weberian fashion - that is, through ideal types - they would have to invent many others as well. Fairly to represent the entire tangle of historical cause and effect, they would need a landowning type or (which Weber did study at length) a bureaucratic type, a military type, and so forth. On the other hand, despite speaking of national character, his analysis disregards political boundaries quite confusedly to reach all over western Europe and the New World.

A good illustration of the methodological problems here lies in England, part Protestant, part Anglican. The latter through its catechism of 1662 taught the person who sought confirmation

27 Values supply the drive, cf. above, n. 18; Arts et al. (2003, p. 4) "following the ideas of Weber and Durkheim, [who] believed that values are prime guidelines in people's lives"; or Barbalet (2008) 36, "for Weber, values define human purposes and are the non-rational attributes of agency that sustain rationality".

28 Above, chap. 3 n. 139; "ethical Lebenstil”, recalled in Tribe (1988) 30.

29 On affect in economic decisions, see, e.g., chap. $3 \S 1$, above; on long-term trait-effects, cf. Mischel in chap. 1, above; on values and social relations, e.g., reciprocity or treatment of the unemployed, cf. above, chap. 3 and Levy et al. (2006) 96, where the Protestant work ethic is treated as a standard trait-cluster. 
To honour and obey the Queen, and all that are put in authority under her: To submit myself to all my governors, teachers, spiritual pastors and masters: To order myself lowly and reverently to all my betters... and to do my duty in that state of life which it shall please God to call me. ${ }^{30}$

In contrast was the Cromwellian side and, after the Restoration, John Bunyan and his contemporary, the very prolific and widely read theologian Richard Baxter. It was on these figures that Weber focused. The Protestant vision of social relations had been fixed by Calvin and his followers of every sect, who in Europe were encouraged or, more truly, were instructed by their doctrines to believe in "the Dignity of Labor and Predestination.”

A man could still demonstrate his inclusion in the ranks of the Elect through success in worldly affairs, especially commercial enterprises... There were still marked differences between the haves and have-nots. The old social categories remained: nobles, knights, merchants, and artisans. Yet now they were blurred. Nobody's status was irrevocably fixed by genealogy, for a man could rise legitimately by his own endeavor from rags to respectability, and even honor. ${ }^{31}$

National character in England was thus no single thing, as Weber would have it, but a mix of two churches and two social doctrines.

In the New World, this old world of haves and have-nots was at first replicated, though perhaps more in habits of mind than in realities. Forms of address in the traditional way defined gentleman, esquire, mister, and master; rules of decent behavior were interpreted in the light of status. Anglican prayer books taught children submissive acceptance of their place, the lesson unchanged since 1662, and Protestant preachers, too, like the Calvinist Jonathan Edwards in the 1730s, reminded all of "their appointed office, place and station, according to their several capacities and talents, and everyone keeps his place, and continues in his proper business". ${ }^{32}$ But the American historian Gordon Wood points out, "The Puritan ethic was widely preached, but only for ordinary people, not for gentlemen". ${ }^{33}$ Gentlemen and those of still higher status didn't have a proper business, or any at all, if business meant working not owning. Wood sets them at less than a tenth of the free population at the time when, near the mid-century, Benjamin Franklin established his claim to be one of them, withdrawing himself from all his former employments. ${ }^{34}$ We can see two quite different worlds coexisting, one dominant in its leisure, traditions, lineage, wealth, education, manners, and the general respect; the other, supported only by self-respect and the Protestant spirit of possibilities.

30 Convenient in Hinde (2002) 98 or Mullin (1989) 8, the prayer book quoted, "My duty is to order myself lowly and reverently to all my betters".

31 Lawrence (1988) 76.

32 Above, n. 30, on the Anglican catechism; and on the Anglican church favored among the haves, Wood (1992) 201; 19, Edwards quoted.

33 Mullin (1989) 16; Wood (1992) 33.

34 Wood (1992) 30f. on proportions in the population. 
However significant the workings of this latter spirit had been in Europe in its Heroic Age of the seventeenth century, they were still more marked, because less impeded by custom, in Franklin's new world of America. Here is a second population group, overlapping with Weber's, which can be used to show the relations between way of life and historical outcomes. In the British colonies changes were under way, not novel in character but in scale, which at an increasing rate simply transformed society even within the space of a single generation. Let us choose the years from 1745 to 1775 as illustration.

Visible and quantifiable changes are naturally the ones with which to begin an account. The rise in population is what might first strike the eye, a result of both a high birth rate and immigration at unprecedented levels from Ireland, Britain, and Germany. The majority of newcomers settled in the towns, where former customs of dependency and deference need not be re-established or were maintained only for a time under indenture. In this urban scene, economic opportunities along the eastern seaboard grew at a rate also unprecedented; small commercial and manufacturing enterprises proliferated. Here was freedom, here was opportunity. Behind the cities to the west, newly won territory opened up to purchase and settlement by the millions of acres, rewarding speculation and new fortunes as well as new farmsteads and riverside towns. The whole very vital, active picture is familiar in the textbooks.

In that one generation 1745-1775, what is most easily known because it left the most ample record in writing was the effect of change among the upper tenth. Benjamin Franklin supplies an illustration, convenient because of his appearance, above, as Weber's model. In his retirement from his printing house and rich from its proceeds, he involved himself repeatedly in the scramble for western land grants from the Crown, where the files are indeed very full of correspondence and of legal documents generated by individuals or most often by small groups of more or less wealthy, influential investors. They sought territory freed up through the extermination or hoodwinking of the Indian occupants in the Ohio valley and thereabouts. Two efforts of this sort were Franklin's, petitioning in 1756 for grants on both sides of the river. In the end, he was unsuccessful; but ten years later he joined the Illinois Company, which was asking for 1,200,000 acres in the Mississippi valley, and then also the Indiana Company in a third area; and in 1769 through the Grand Ohio Company he and associates with stupendous greed petitioned for twenty million acres. It would have been "the greatest speculative coup of the eighteenth century" - balked, however, by politics in London and the American colonies. ${ }^{35}$

Franklin's story in these years of speculation incidentally suggests a terminal point for Weber's thesis, with the transformation of the Protestant ethic into something very

35 Billington and Ridge (1982) 147, “extermination” of the Indian "vermin” proposed by the Indian affairs minister, through infecting them with smallpox; on land speculation, 146, 153, and 159 (quoted); on Franklin's, Labaree and Bell (1959-2011) vol. 31 (1995) 525-47. 
remote from its Calvinist origins. Beyond that, however, the scale of the ambitions in which he was caught up shows how powerfully enticing were the possibilities opened up to the generation, 1745-1775. At its start and earlier still, land had been in short supply in the older colonies; younger sons who wanted marriage and independence were simply out of luck; but from mid-century on, the movement of new settlers from the more heavily farmed parts into unexploited regions in New York, northern Connecticut, Pennsylvania, or the Carolinas, increased at a remarkable rate. Of this rage for land, Franklin's speculation was only one early sign. ${ }^{36}$

Before the mid-eighteenth century those younger sons, and all but a small minority of the immigrant thousands, had known only a world where every square inch of land was bespoke. Anyone with little or none must live with the consequences - meaning submission and dependence in the face of patronage and control. What now, however, began to appear as the most consequential difference defining the New World was the great freedom of movement its society allowed and the closely related abundance of unoccupied land. There was more than enough room for that most extraordinary increase in the colonies' population, more than doubling in the one generation post-1745. In addition, coastal towns grew into cities and with them commerce picked up, joining them to inland agriculture and to maritime and overseas trade. Prosperity from the 1740 s took hold and with it, rising expectations open to every rank and region. "The growth and movement of people strained and broke apart households, churches, and neighborhoods" - in sum, much of the fabric of place and obligation. ${ }^{37}$

To trace the consequences takes me among the ethical tendencies that shape a society, announced as a target of interest at the beginning of this chapter. They are to be seen as the eventual rather than the immediate consequence of interaction with changes in the economy, in population, or any such large causal factors. First, one takes advantage of material changes for material reasons; and on these, historians will fasten as the easiest thing to observe and quantify. They are rational. Only later, one might begin to feel that one's ideas of what was proper were in conflict with experience and should better reflect new realities. One's future decisions would thus be reconfigured, and on a more consequential scale, too, responsive to a general sense of what everyone around seemed to be doing. The effects would show in the prevailing code of behavior, the collective character.

The question whether or not to refuse obedience to one's king presents us with a test of such effects. At a juncture of dire need, Britain's treasury being worse than empty, its debts enormous after seven years of war only ending in 1763, the royal

36 Wood (1992) 50, $127 \mathrm{ff}$.

37 On the demography, Wood (1992) 124-28; prosperity of 1740s-1750s, 133ff.; quoted, 129; but Hoerder (1977) 30 points out the rising land prices in New York which limited opportunity for escape from older family farms and townships. 
government proposed to raise money from the colonies for their own defense. Hence, the Sugar Act of 1764, the Stamp Act of the next year, the Tea Party, and so on to Lexington. The path to that end has been traced a thousand times. What will ordinarily be offered to explain the colonists' disobedience are the surviving written expressions of protest or outrage. Commonly, they take the form of editorials or pamphlets embroidered with tags of a classical education and appeals to philosophy, above all, to John Locke and the logic, as it was seen, implicit in an imagined state of nature; almost as lofty, the recall of Magna Charta and the British origin and therefore British rights of the colonists. At greater length, follow fine points of law in the founding charters, the individual's proper rights and expectations, and, not least, the great money-losses to be suffered from parliament's exactions. ${ }^{38}$ Written advocacy for the most part thus represented the upper classes who in addition to their education and perhaps added legal training drew their income from their various property rights and loans. All these must surely be affected by the king's demands. Their calculations, or in today's terms their business model, can sometimes be traced in detail. ${ }^{39}$ Surely, too, the defiant reaction of the polemicists is rightly understood as a consequence of the attenuation of their ties to London, so far away, and their habituation to a great deal of self-government, so much a part of their lives. Their motivation was thus mixed. They had come to expect what had once been a novel and increasing degree of independence, now in jeopardy. They had been taught by their actual experience over the decades; and "expectations" are only another word for "rights". In the written record of the colonists' response, this latter word is their big gun. Violation of rights they declared insupportable. It was a moral matter, and nothing is more certain to produce anger among the wronged, whether or not any material injury also is felt. ${ }^{40}$

My understanding of the story told in these traditional terms is meant to bring out the causal links between the colonial leaders' experience in their setting, the effects of that setting on their ideas of right and wrong, and the irresistible urge to protest, even with force, that possessed them in the 1760 s and 1770s. To my mind, not only is the causal chain here easily traced in the written evidence, but easily accepted. It makes sense. However, to repeat what was said earlier, there were within the population two different worlds, of which one was composed of leaders, the "haves". Now, these latter saw things in their own way, as has been seen. But there were also the "have-nots" who, except as their behavior is described for us by writers of the better

38 Thucydides, in Hopkins (1765) 6 or Bland (1766) 27; Brutus, in a 1770 public letter, Carp (2010) 84; Locke, e.g., in Otis (1764) 5, 22, and passim; 6, the state of nature as template proposed for the rise of civilized society; Bland (1766) 9, 11; or in Paine (1792) 8, 20; Miller (1949) 169ff.; Gilje (1987) 8; or Jared Ingersoll in 1764 on "natural and Constitutional rights", Middlekauff (2005) 76; Magna Charta recalled by the writer quoted in Countryman (1993) 132 or Paine (1792) 20; legal arguments, e.g., Bland (1766) 4ff., 8ff., or Hopkins (1765) 5f., 8ff.

39 Carp (2010) chapters 5-6 on Francis Rotch of Boston provides a good example.

40 Chap. 3, above, at nn. 100ff., $110 f$. 
sort, hardly appear in the surviving record. They present a problem to our understanding which repays examination.

Clearly in pre-industrial times it is misleading to speak of classes. There were, however, plainly acknowledged distinctions. Dirk Hoerder's discussion of these seems the best, drawing as it does not only on a good deal of theoretical discussion, but also on a very full knowledge of the scene at least in Massachusetts. He accepts the style of contemporaries, denominating "the better sort" as those on top; and he accepts also real differences of which contemporaries were quite evidently aware, between the top and all those beneath them; but it was a matter not only of money but of entitlement as well. It was proper for gentlemen to be in charge. As illustration, there is John Adams insisting in the early years of the Revolution that

there is one thing... that must be attempted and most sacredly observed, or we are all undone. There must be a decency and respect and veneration introduced for persons in authority of every rank, or we are undone. In a popular government, this is the only way of supporting order. ${ }^{41}$

I notice how "we" in Adams' statement sets him and his audience, all of them together "in authority", apart from "them" - who are everyone else.

Each of the two ranks in its own way made the Revolution, not only the be-wigged gentlemen so ready with their quill pens and elegant argumentation. Notoriously, crowds as well, some in the thousands, played a part. Indeed, as the dramatic and dynamic element necessary to the making of history on a grand scale, they attracted much notice at the time and since. Something is known about their composition. At different moments they embraced almost all socioeconomic levels: the respectable (perhaps disguised, and not including the most eminent) down to "boys and Negroes". ${ }^{42}$ The motive that united them in action need not remain obscure, at least at a superficial level. They represented a demand for liberty. The colonists' most eloquent voice in Parliament had, in a speech of February 1765, described them as "the sons of liberty" - a familiar image, since Englishmen had long called themselves free and valued themselves in that quality against the French and other nationals who cowered under their kings. In the colonies, the claim of freedom was the same as the

41 Hoerder (1977) 7f. on John Adams; 38 and 71-77 on class; and 10, on "the middling interest" to indicate an intermediate stratum defined by its economic goals, but otherwise "difficult for the historian to trace"; so he generally sees a scene of the haves and have-nots (in my own simplifying terminology). Hoerder's tripartite division of society appears in Wood (2009) 28, noting that "Most people did not yet think explicitly in terms of modern 'classes'... that would become common forms of identity in the nineteenth century" (etc.); and 171, further on the ideas persisting into the late eighteenth century. 42 Crowds often described, e.g., by Miller (1949) 131, 143, 302, 371; Morgan and Morgan (1953) 181; Countryman (1981) 59; Gilje (1987) 83 and passim; Middlekauff (2005) 92f.; Carp (2010) 37, 131, 234-39, and passim; and especially Hoerder (1977) chapter 2. Adams in March 1770 describes the victims of the "Massacre" as "saucy boys, Negroes and Mulattoes, Iris Teagues, and outlandish Jack Tars", cf. Bourne (2006) 167; Gilje (1987) 12-14 uses the pair “patrician” and “plebeian”. 
claim of English derivation, and it was therefore natural for the honorific title to be taken up by the protesters in Boston, and soon elsewhere, to denominate local "Sons of Liberty" cooperating with each other. ${ }^{43}$

But this implied demand of theirs doesn't say what exactly they were to be free to do, or free not to do, or why and how they could wax so furious. The scourge of impressment by royal navy squads in seaports was a special separate affront, though it obviously involved the liberty of its victims; ${ }^{44}$ but the greater part of the crowds gathered and angry or violent against the Sugar Act or the Stamp Act cannot have been hurt, or threatened with any material loss, by those measures. ${ }^{45}$ Gordon Wood contends, rather, that "the Revolution brought respectability and even dominance to ordinary people long held in contempt and gave dignity to their menial labor in a manner unprecedented in history." ${ }^{46}$ Revolution alone could elevate so ill-paid and little respected a thing as a cobbler to a position of authority, though it might be for no more than a moment at the head of some shouting throng of men in the streets. For such a person the reward in demonstrating seems to have been as Wood says, a claim on dignity.

The Boston cobbler Ebenezer MacIntosh, then in 1765 in his late twenties, a volunteer fireman, was approached by a small group of gentlemen to enlist his support and that of two elements in the population, the Northenders and the Southenders. They were known as "mobs", and they liked a scuffle. MacIntosh was the leader of the Southenders in the annual Pope's Day parade, the colonists' version of Guy Fawkes day, and was acceptable to represent both mobs united. The physical force he headed was to be aimed against one Andrew Oliver. This Oliver was prominent, wealthy, and hated as the royal agent for the collection of the stamp tax, along with all his equally detestable and profiteering agents and his far-from-popular brother-in-law, the lieutenant-governor himself. For a fortnight in August the mobs were front-page stuff. At least at the start their actions were generally approved, even blessed by the clergy. As the scene heated up, several houses were broken into and thoroughly trashed, their owners barely escaping. ${ }^{47}$ On balance, however, the mobs seem to have ended on

43 Otis (1764) 69, fear to be "reduced from the character of free subjects to the miserable state of tributary slaves"; "Liberty" as opposed to slavery as the opening word of Hopkins (1765) 3.

44 Lemisch (1968) 390, 407, and passim; impressment at its worst in Boston and the 1740s, though much in the 1760 s, too.

45 Morgan and Morgan (1953) 181, "Actually the lower classes probably had little to lose directly by the Stamp Act”; Miller (1949) 111, “the [Stamp Act] tax fell upon those best able to pay”; Kulikoff (1993) 93, the Stamp Act had little effect on the rural yeoman class; and Wood (1992) 169, "there was little evidence of those social conditions we often associate with revolution (and some historians have sought to find): no mass poverty, no seething social discontent, no grinding oppression".

46 Quoted, Wood (1992) 8.

47 Hoerder (1977) 96, 101, clergy, and 112f., MacIntosh arrested but quickly released; Middlekauff (2005) 93-97; Carp (2010) 32, 36, 43 (a teenage kinsman a victim in the Massacre). 
the winning side, whatever may have been thought about the violence they showed to property.

Not only in Boston but in many other cities, New York in chief, and in small townships in rural New York as well, demonstrations were not an uncommon feature of life throughout the eighteenth century. They came in all sizes and in every temperature, from warm to boiling. In European history from Antiquity on, in one city or another at one time or another, those who were ruled could express their wishes without a formal vote but by collective noise and speech, and were really listened to by their rulers, in what can only be called democracy (though the modern age reserves the term for a narrow part of the possibilities). The Southend cobbler, MacIntosh, was in this radical sense a democratic leader without being a radical. The better sort acknowledged the distinction and accepted - indeed they invited - his role on behalf of the entire city, so far as it was anti-tax. They needed him and his men. The "dignity" of which Gordon Wood speaks was thus his reward and may be fairly taken as his motive and, in a less intense way, the motive of his following as well. He had been elevated to equality with the better sort, if only briefly and by their leave. He and his following were to act out this honorable part before the whole city as their audience.

As the first day, the good day, degenerated into more violence, vandalism, and drunkenness, the full spectrum of common crowd behavior was illustrated, and the reaction to it of those uninvolved on the sidelines. They could approve a demonstration, they could even accept one as "constitutional", so long as it was well behaved and called attention to real public concerns. They were used to that. ${ }^{48}$ On the other hand, they feared and condemned the threat to order, if it was also a threat to life and property. What they perhaps understood was that - in the view of the populace, not of the better sort - the gap between the ordinary man in the street and the very wealthy was in itself a public concern; and this was evident in the pattern of vandalism and destruction of property (not theft). It was directed at profiteers and showoffs, people seen and detested in the streets for their costly coaches and jewelry, their silver cane-handles, shoe-buckles and buttons, on their way to some glittering theater performance. A matching luxury and display when their grand homes were burst into was sure to provoke the mob's outrage at the gap, as unfair; and so much of such high style was imported from England, too $!^{49}$ Hence, more justified anger; for, as an anthropologist says in generalizing terms about all societies known to his science,

48 Gilje (1987) 8, 17, 23; Middlekauff (2005) 104, "rioting had a long and apparently honorable history in Newport”; Hoerder (1977) 80, quotations to show gingerly acceptance of legitimacy of demonstrations, as "constitutional"; 84, "riots were recognized as part of the contemporary social and political institutions"; and 117, "the public good" at stake.

49 On the finery as detestably British, Miller (1949) 149f.; Hoerder (1977) 74f.; or Countryman (1981) 48f., 59f.; on anger at wealth, see Gilje (1987) 44, 50f. 
"injustice, unfairness, and lack of reciprocity often motivate human aggression and indignation." The subject was discussed above. ${ }^{50}$

Lastly, on the essence of the gap: it represented inequality in violation of plain ordinary justice. It took on historical significance on a grand scale, as Paul Gilje pointed out: ${ }^{51}$

The repeated use of crowd politics, expressed in traditional plebeian ritual [such as Pope's Day], had some unexpected consequences as the innate sense of fair play implicit in that ritual gave way to incipient egalitarianism. This politicization of the common man, clearly linked to the heavy dependence on crowd activity from 1765 to 1776, pushed the Revolutionary leaders to reformulate their own conception of good government... laborers, seamen, and mechanics assumed they had a voice...

And Gordon Wood again adds that, "once invoked, the idea of equality could not be stopped, and it tore through American society and culture with awesome power." 52

Another cobbler like MacIntosh was a little short man (an inch over five feet) with a long name, George Robert Twelve Hewes. He spent his whole life in and out of destitution. It was this unlikely hero who stepped forward to tend to a dying man at the scene of the Boston Massacre in March of 1770 and was present again as a volunteer and assault-party captain with the Tea Party patriots three years later. On the day after the Massacre he testified in court:

On his way back to the Town House with his cane he had a defiant exchange with Sergeant Chambers of the Twenty-Ninth Regiment and eight or nine soldiers, 'all with very large clubs or cutlasses.' A soldier, Dobson, 'ask'd him how he far'd; he told him very badly to see his townsmen shot in such a manner, and asked him if he did not think it was a dreadful thing.' Dobson swore 'it was fine thing' and 'you shall see more of it.' Chambers 'seized and forced' the cane from Hewes, 'saying I had no right to carry it. I told him I had as good a right to carry a cane as they had to carry clubs'. ${ }^{53}$

It was in encounters like this that the relaxing of patronage and dependency at work in the generation leading up to 1775 could be seen - and not only in the better reported cities but in rural townships as well, among small farmers and tenants. ${ }^{54}$ Contem-

50 Above, chap. 3 n. 113.

51 Gilje (1987) 42, quoted.

52 Wood (1992) 232.

53 Young (1999) 39; for an exactly similar situation and behavior, involving a ropemaker, see Countryman (2000) 155.

54 Countryman (1981) 24, 40, 48ff., especially 71, that "crowd action stretched and rent the fabric of New York [up-state] society" in the period 1750-1775, and "nearly continuous rioting in one place or another built up a tradition of rural protest". Similarly, Young (1993) 324 on Robert Hewes (with some exaggeration), that "the experience of participating in the Boston Massacre, the Boston Tea Party, and countless other events of resistance enabled him to cast off deference". 
poraries noticed the rising freedom of demeanor and speech among the have-nots, among whom cobblers and rope-makers and agricultural tenants were most obviously numbered and yet, being so humble, were proud and prickly beyond all expectation. ${ }^{55}$ The assertion of individual rights and independence, whether in the face of a local elite or of an imperial government and its military, had evidently become more acceptable or at least less risky in the New World than in the Old. So much is clear. Experience reinforced it as it gained acceptance; and it was an ungovernable spirit. At the end, "the conflict that tore the British empire apart between 1754 and 1783 drew upon the deepest moral passion of Americans of virtually every sort and status." 56

If among Americans the ungentlemanly nine tenths have left so little in print to explain the change in moral culture, Tom Paine may speak for them at the turn of 1776, "not inflaming or exaggerating matters," as he says, "but trying them by those feelings and affections which nature justifies, and without which we should be incapable of discharging the social duties of life or enjoying the felicities of it." ${ }^{\text {" Com- }}$ mon-Sense sales of half a million within a year show how his words resonated even among the masses, and give weight to his view that it was popular feelings that drove events, or moral passions to repeat the term used above.

Paine's view fits well with the approach taken to historical causation in the present chapter and in the preceding one as well. Beliefs about right and wrong may change for all sorts of causes, external as well as internal, but the new like the old will be acted out at the urge of associated feelings. Emotion supplies motive force. Whole populations like individuals act in characteristic ways, too, which when observed in an individual would be called "traits" comprising personality. Similarly, in a population, traits may be called "collective character", whether of a nation or a class of people. Character determines the general direction of conduct if not, certainly, each twist and turn.

In the demographic and territorial environment that the colonists in part created, over the generation 1745-1775, and in part found ready waiting for them, it is tempting to see the heart of Frederick Jackson Turner's famous thesis. This, and its elaboration by its author and his students, may serve as a third illustration of how culture as cause can be treated on a grand scale. In shaping the discussion of the American narrative, Turner's ideas enjoyed an influence unmatched in the twentieth century. He sought to explain "how European life entered the continent and how America modified and

55 Woods (1992) 145 draws on Charles Carroll of Maryland in 1765 to generalize, that "in all the colonies... any mark of superiority, any pretension of aristocracy, was 'sure to entail a general ill-will and dislike upon the owner'. Threats and anger were becoming more common than mutual respect and deference".

56 Middlekauff (2005) 30f.

57 Paine (1792) 15f. Eustace (2008) 3 and 440 stresses "Paine's emotional tone" but focuses not on how it worked on readers and made history, but rather on the propriety of feeling and expressing emotions, as discussed among the Colonial elite (4ff., 121, and passim; 393, "genteel sensibilities"). 
developed that life and reacted on Europe" - and by "life" of course he meant "way of life" or culture, not simply biological existence. "Our early history," he continues, "is the study of the germs developing in an American environment.” To the early period, in our first two hundred years, he gave little attention. What rather interested him was "the really American part of our history", meaning the settler's world of the untamed fringes and what such regions gave rise to: a personality "strong in selfishness and individualism”, as he says, most evident after 1815 or 1820 . "The frontier is productive of individualism... [and] frontier individualism has from the beginning promoted democracy". These twin processes were the two legs on which his thesis stood. ${ }^{58}$

It was the underlying assumption here that a group or collectivity of whatever sort will have a personality that will in some degree reflect surrounding conditions. The proposition so broadly stated seems unobjectionable, just short of banal. It underlies my own outline, above, of the urges and values characterizing the have-nots of 1745-1775. Turner's thesis nevertheless provoked a welter of critical discussion. One of his students who was also an admirer and who made an honorable place for himself in the same line of studies, Ray Billington, was dismissive of American individualism as "fiction", "myth", “folklore", and "legend" except in pursuit of material profits, while Gordon Wood pronounced American society as the most individualist in the Western world - but he mentions Turner only once, to find fault with him. ${ }^{59}$ How well the thesis has survived all such scholarly back-and-forth is, however, of less interest to me than one feature of Turner's style. He does not shrink from involving both himself and his readers in the affective aspects of the scenes he describes - as, for example, in an essay of 1903. Here he directs attention to the rise of "democratic influence" in America of the period 1800-1820, at which "the established classes in New England and the South began to take alarm. Perhaps no better illustration of the old-time Federal conservative" can be found, he says, than in a passage drawn from a travel book of 1822/3 by the Yale College president Timothy Dwight: ${ }^{60}$

58 Quoted from the original essay of 1893, Turner (1920b) 3, 32 ("selfishness"), 30 ("productive of individualism"); and his concluding long paragraph is given to the resulting "common traits" of Americans, including "that dominant individualism"; also Turner (1961) 68f. or Turner (1920) 320 of 1911, or Turner (1920a) 254, "the unchecked development of the individual was the significant product of this frontier democracy"; (1920b) 4, "the really American part". On the "two legs", in slightly different words ("concepts"), see Billington (1966) 139.

59 Much criticism, e.g., Berkhofer (1981) 43f.; Cronon (1991) 90f.; Billington (1966) 142f., 146, and 148, echoed by Brown (2009) 40, 48, "mythmaking”, "dream world”, “myth"; but cf. Billington and Ridge (1982) 687, on "the distinctive form of individualism that Europeans still associate with those reared in America. To the pioneer, every person was a self-dependent individual”. Similarly, Wood (1992) 230, "by the early nineteenth century America had already emerged as the most egalitarian, most materialistic, most individualistic... society"; but, 311, Turner is faulted for leaving out too many causal factors; and his name is conspicuously absent in Wood (2009).

60 Turner (1920a) 251f., with no specific reference and slightly misquoting the first half-dozen words (the passage is in Dwight [1969] 4.321f.); and 261 (“Western democracy”, quoted). 
The class of pioneers cannot live in a regular society. They are too idle, too talkative, too passionate, too prodigal, and too shiftless to acquire either property or character. They are impatient of the restraints of law, religion, and morality, and grumble about the taxes by which Rulers, Ministers, and Schoolmasters are supported... After exposing the injustice of the community in neglecting to invest persons of such superior merit [as themselves] in public offices, in many an eloquent harangue uttered by many a kitchen fire, in every blacksmith shop, in every corner of the streets, and finding all their efforts vain, they become at length discouraged, and under the pressure of poverty, the fear of gaol, and consciousness of public contempt, leave their native places and betake themselves to the wilderness.

The passage is well chosen to discredit Dwight's views, with which Turner diametrically disagreed. The Yale president is shown at his most unpleasant. A century after the publication of the passage quoted, in Turner's own day - to say nothing of our present times - the man's cruel caricature could only repel readers and provoke their dissent. In contrast a few pages later, Turner instead offered a strikingly different characterization:

Western democracy has been from the time of its birth idealistic. The very fact of the wilderness appealed to men as a fair, blank page on which to write a new chapter in the story of man's struggle for a higher type of society. The Western wilds, from the Alleghenies to the Pacific, constituted the richest free gift that was ever spread out before civilized man. To the peasant and artisan of the Old World, bound by the chain of social class, as old as custom and as inevitable as fate, the West offered an exit into a free life... The existence of this land of opportunity has made America the goal of idealists from the days of the Pilgrim Fathers. With all the materialism of the pioneer movement, this idealistic conception of the vacant lands as an opportunity for a new order of things is unmistakably present.

- and Turner follows this up with a long passage of romantic poetry and lyric bits of prose not from common settlers but from Roger Williams and William Penn.

In another passage often offered to show both his magic and his method, he expatiates on

That coarseness and strength combined with acuteness and inquisitiveness; that practical inventive turn of mind, quick to find expedients; that masterful grasp of material things, lacking in the artistic but powerful to effect great ends; that restless, nervous energy; that dominant individualism, working for good and evil, and withal that buoyancy and exuberance which comes with freedom - these are the traits of the frontier, or traits called out elsewhere because of the existence of the frontier. ${ }^{61}$

Such fine writing as Turner's has, or it once did have, its place and audience, certainly; but then, so did Timothy Dwight's in its time; and if one is to take science as the model for historical analysis, the stylists are equally at fault. They are too obviously

61 Quoted in Cronon (1991) 84; 83, he "articulated his thesis as a catalogue of 'character traits' that were the results of American evolution". 
subjective. Instead, the sources need to be opened up as if to a jury, emphasizing the observation of signs of motivation as well as overt acts as they are reported by eyewitnesses; characterizing the witnesses by status and point of view; and taking care not to select only data that fit one's ends. None of these rules of argument, at which my own treatment of the "have-nots" aimed, is observed by either Dwight or Turner; so there is no good way to choose between them. Readers have only their own equally subjective reactions to go on, in believing the one or the other. It is indeed by just this everyday process that the historical profession arrives at its consensus, and declares one or another interpretation of events to be right.

Turner, however, engaging his imagination in the scenes he describes, evidently believed he could empathetically discern the feelings that explained behavior and, further, that those certain feelings typically animated the group he was interested in. Feelings shaped life and revealed prevailing values; and values are "the mediating variable of interest that connects to culture". ${ }^{62}$ This, as Turner showed, is a fact that bears on choices made in the preferred form of government - government, among other things. Should it be authoritarian, or democratic? In this question and all its implications, historians have an obvious interest.

At the center of Turner's thesis was a personality of a certain sort that found increasing acceptance among historians. Over time and in a way he could not have been foreseen back in 1893, the key element in that American personality was also identified by an entirely different discipline, cross-cultural psychology, as the preceding chapter explained. ${ }^{63}$ Individualism was Turner's very word; and individualism without any consciousness of his thesis was what psychologists beginning in the 1970s focused on more and more in their own way. It was a big part of their favorite subject, namely, Americans, increasingly seen in comparison with personality-types dominant in other societies. The comparison has occupied the EVS and WVS; and personality types as a concept could be fitted into the idea of modal personalities, familiar in anthropology. ${ }^{64}$

62 Bond (1994) 74, quoted; Yu and Yang (1994) 246, "society prescribes... goals... individual goals must conform with the values of the in-group" which thus give direction to achievement, cf. also 250; and Helwig (2006) 198, $202 \mathrm{f}$.

63 Above, chap. 1 at n. 39 and elsewhere; chap. 3 at n. 134.

64 On "modal" personality in anthropology, see above, chap. 2 at nn. 37f. Smith et al. (2006) 46, 51, and 142, argue that "the values of an average person will give only a weak indication of the context within which that person is operating. We will do better if we know more about the way that an overall average set of values is distributed among the population... [C]haracterizing a whole nation as individualist or collectivist is at best a convenient shorthand... [I]t is individuals, not nations who possess these types of qualities [such as Assertiveness, Human-heartedness, Loyal Involvement]... Their mean values [of the "Big Five" personality traits] do not, of course, characterize each individual, but they do provide a sense of the typical personality...”. On "the Big Five" traits, see above, chap. 1 at n. 28; on individualism/collectivism and Confucianism, and prevailing work ethic in EVS/WVS, see Halman et al. (2005) 54 . 
Contrast was first and most fully drawn with Japan and its collectivist society. To all the resulting research there could be no better introduction than an article coauthored by two veterans of cross-cultural psychology, Hazel Markus and Shinobu Kitayama. In their opening pages before taking up more technical matters, they recall how one of them left her home to teach in Osaka, while the other left his, for advanced study in Ann Arbor. ${ }^{65}$ They had each been astonished at "finding ourselves in worlds that did not make sense with people who were behaving in strange and unfamiliar ways". Markus had never expected, in response to her lectures and still after many weeks into the term, that no student "said anything - nothing - no questions, no comments... Where were the arguments, the debates, and the signs of critical thinking? And moreover, if you asked somebody a completely straightforward question such as, 'Where is the best noodle shop?' why was the answer invariably an audible intake of air followed by the response, 'It depends'”. On the other hand, Kitayama couldn't understand students continually interrupting each other and talking over even the professor; and the high level of emotions and competition was strange, and the professors' trick of starting a lecture with a joke, and the behavior of students and faculty alike at restaurants.

There were endless things to notice, fascinating to these two trained observers - especially the "dynamic interdependencies between psychological tendencies and the sociocultural, sociostructural, and sociohistorical situations and contexts in which these tendencies occur" (descriptive phrases that Turner might have approved, hearing his own core ideas compressed into the latest techno-speak). The authors go on to support with their findings the pairing most familiar in their field, individualism vs. collectivism, as personality types shaped by culture. Where the types differ, it shouldn't be seen as a matter of cognitive content. Indeed, as they say, "meanings and values may not be cognized and stored in memory at all. Instead, they may be so deeply ingrained in the everyday mundane practices of the culture that they are 'lived' rather than being 'known' or 'cognized'”. These very findings in studies without cultural connections appeared (it may be recalled) in the preceding chapter. ${ }^{66}$

As to a cultural background, collectivism in Asian societies has been most often associated with Confucianism (a conclusion on which Weber in his turn might have smiled, seeing in Confucianism the same formative role he assigns to Calvinism). It teaches subordination of self to family, to age, even to those departed, that is, tradition. It marks the wish not to stand out; to be a team-player in one's place of work; to defer to the common will and established authority. Individualism on the other hand shows itself in a willingness to act on one's own even unsupported by one's group; in the preference for authority that will recognize one's right to be different and inde-

65 Markus and Kitayama (2003) 278f.

66 Markus and Kitayama (2003) 277, 280, 283; also Markus and Hamedani (2007) 12. On unconscious responses, see also above, chap. 3 at nn. 62 and 112 . 
pendent, and the equal claim of every person to be heard; in tolerance of rivalry, novelty, and disregard of convention. While the contrast between the two cultural tendencies is usually discussed in East-West and contemporary contexts, and with an eye to practical applications, African and other examples receive social-scientific attention, too. ${ }^{67}$

The recollections of Shinobu Kitayama and Hazel Markus, and individualism vs. collectivism, and comparison of cultures - all these together serve my interest in culture as a cause of historical events and developments. Returning now to that focus, three points stand out, of which the first is perhaps the most obvious: that national character is simply a given among modern psychologists, whether cross-cultural or not. They assume its existence without need to support their assumption; and, for that matter, so do the anthropologists seen in my second chapter dealing with collectivities not as large as nations, and the sociologists conducting their values surveys. As a reminder of the deep roots of these views in the social sciences, here is the sociologist, anthropologist, and historical linguist, Edward Sapir, speaking of the French nearly a century ago: ${ }^{68}$

\begin{abstract}
No one who has even superficially concerned himself with French culture can have failed to be impressed by the qualities of clarity, lucid systematization, balance, care in choice or means, and good taste, that permeate so many aspects of the national civilization. These qualities have their weaker side. We are familiar with the overmechanization, the emotional timidity or shallowness,... that are revealed in some of the manifestations of the French spirit. Those elements of French civilization that give characteristic evidence of the qualities of its genius may be said, in our present limited sense, to constitute the culture of France.
\end{abstract}

As a second point equally clear, national character is seen to control national behavior on what may be called an historical scale - at least (but not least interesting) in the achieving of economic success. The favored explanation for this is sought in the comparison of Confucianism with Calvinism. Both these thought-systems serve the businessman but not at all in the same way. ${ }^{69}$ If one wished, too, the effects of

67 On collectivism contrasted with individualism, see especially Triandis (1995) passim and the volume with many articles edited by Kim et al. (1994); also, e.g., Fiske (1992) 697f., Matsumoto (1994) 119, or Oishi et al. (2008) 307; on Confucianism as a business ethic, Kim et al. (1994a) 6f., Yu and Yang (1994) 240ff. and 245ff., Triandis (1995) 26, Helwig (2006) 199ff., Kim and Park (2008) 500f., or Khilji et al. (2011) passim.

68 Sapir (1924) 407, quoted.

69 Economic effects of philosophic/religious factors extend beyond Weber to research in contemporary Asian countries, cf. Yu and Yang (1994) 241 or McCleary (2007) 49 emphasizing values such as honesty and frugality; Furnham (1990) 19 and Landes (1998) 391, 487f., on "the Japanese economic miracle" explained by collectivism and the competition of groups not individuals; and Franke et al. (1991) rating economic performance across 20 nations and concluding that "performance seems facilitated by Confucian dynamism” (meaning, p. 167, acceptance of hierarchy, thrift, perseverance), 
national character could be shown in the preference for one political system over another, authoritarian and doctrinaire as opposed to pragmatic and empiricist, thus to be studied on the lines of Turner's thesis and its links with American democracy. And so forth.

But as a third point to notice: in contrast to historical treatments, social-scientific studies are generally synchronic. They don't pursue a train of development within a population, traced from some external stimulus to a widespread consciousness of it, and so to action at the urging of responsive instincts or strong feelings, at the end producing a change in values and traits. All this is cinema, not still photography; and the variables necessarily attendant on such diachronic treatment, in their infinite unpredictability, simply cannot be contained within the laboratory. They don't lend themselves to study in a decently scientific way.

At best, the effect of a thought-system or physical environment on some whole population, so as to shape its character, may be conjectured as a matter of theory not confined to a period of time: for example, by identifying prevailing moral values through research among college students of one nation or another, and suggesting in Weberian fashion how these values must constitute a representative personality that particularly serves, let us say, gainful activity.

But to go further and demonstrate exactly how it so serves has always been the proper business of historians, as Katherine Verdery explains in a recent volume:

\begin{abstract}
For individual members of a nation to experience the world in terms of a self that is national requires bringing together the sense of self and the sense of one's group: self and group must be experienced simultaneously, as constitutive of the person. The notion of a national character establishes precisely such a link. "Character," whether it is taken to be something inborn or something molded by experience, is a notion that can apply equally to persons and collectivities: much as one might explain an individual's trajectory through life in terms of his being of a rigid, uncompromising character or supple and adaptable... ${ }^{70}$
\end{abstract}

Her closing thought, that the dominant traits of a single person or of an entire population equally determine a general narrative, is supported by a great deal of social science reviewed in my pages. It directs attention to what is implied by the comparison or equating of person with population; and it invites our use of certain quite familiar means of sizing up our fellow creatures. We use our eyes, yes, and the recall of what we have noticed before, but also and most important, our powers of empathy. We have seen Joachim or Joanna in action as neighbors or co-workers and out of our life's experience and affective powers, asking ourselves how would we ourselves feel

whereas "cultural individualism seems a liability, while the propensity for work in cohesive groups is an asset”.

70 Verdery (1995) xxv, “'national character', a subject now reemerging after a number of years in the shade” (cf. above, n. 3); and quoted, xvif. 
if we behaved similarly, we can draw our conclusions. We can do this, we believe, even more certainly than from judging whatever they have said. Their actions reveal tendencies. Tendencies reveal choices, and choices reveal moral values. "Values are beliefs that are linked inextricably to affect... when values are activated they become infused with feeling." It is of course a social scientist quoted. ${ }^{71}$

Right and wrong, feelings about them, and the motive behind actions are surely best explained in diachronic fashion - that is, historically. The method is undeniably unscientific in any usual sense. Properly, individual behavior should be observed and described within a given setting, that is (in the term of art) "situationally". ${ }^{72}$ Historians, however, choose to follow their subject through a succession of situations constantly changing, since change is their concern. As a result, their observations become increasingly approximate. True - but what is lost in accuracy is gained in insight into cause and effect. "Y" can be seen following from " $\mathrm{X}$ "; from cause and effect, it is possible to reason to motive, and by this means to control the actors' own explanations if any are offered. Commonly, of course, these do indeed turn up in surviving records; and all these routines of historical understanding are, as Katherine Verdery says, as valid for collectivities as for individuals. They allow the analyst to get inside the scene and its operations as into a novel, which is by no means the worst way to learn about humanity.

71 Schwartz (2007) 170.

72 As illustration of the rules of good analysis, see the back-and-forth in which Walter Mischel and Seymour Epstein engaged, with other researchers in the same area (above, chap. 1). 